\title{
Identification of Migratory Birds and Their Spesific Characteristics of Habitat in the Salt Water Lake of Gili Meno, North Lombok Distric
}

\author{
Diah Purwitasari ${ }^{1}$, Luh Gde Sri Astiti ${ }^{1,2}$ and Supriadi ${ }^{1^{*}}$ \\ ${ }^{1}$ Faculty of Veterinary Medicine, University of West Nusa Tenggara, Mataram, Indonesia \\ ${ }^{2}$ Research Institute for Agricultural Technology West Nusa Tenggara, Indonesia \\ Author correspondency*: \\ supriadi@yahoo.com
}

\begin{abstract}
The aim of this research was to identify the species of migratory birds in the ecosystem of salt water lake of Gili Meno and their specific characteristics of habitat. Data collection for birds, mangrove and fish species has been carried out in September and October 2013. In this study, a Shannon-Wiener Diversity Index and Importance Value Index (IVI) of mangrove vegetation were calculated to identify carrying capacity of mangrove population in the form of specific habitat in salt water lake of Gili Meno. This research has identified 17 species of birds which are divided into 5 families: Scolopacidae, Charadriidae, Ardeidae, Meropidae and Alcedinidae. Moreover, 3 species of mangrove were discovered that are A. marina, A. lanata and E. Agallocha, as well as one species of fish (Mujair fish/O. mossambicus). N. Nycticorax and B. Striatus were well-known to have higher population than other bird species. The Diversity Index showed that mangrove vegetation in the ecosystem of salt water lake of Gili Meno has a low species diversity (0.565). This is due to higher dominance of one species than the others. What is more, the IVI of A. marina demonstrated a fairly significant value compared to that of other species $(189,01)$. Mangrove vegetation which surrounds the ecosystem of salt water lake of Gili Meno has formed a unique habitat and and an ideal stopover site for migratory birds. The ecosystem not only provides shelters from predators but also supplies for various abundant feeding sources. The lake it self is rather shallow and muddy around the shore which gives advantages for the migratory birds to obtain plenty small fish from the lake.
\end{abstract}

Keywords: Migratory Birds, Salt water lake, Gili Meno, Characteristics of habitat

\section{Introduction}

Indonesia is the fifth country after Colombia, Peru, Brazil and Ecuador which have the highest megabiodiversity of birds, as many as 1539 species (Sudaryanto, 2006). Those species are divided into 20 Order and 90 Families (Yamin and Jamaluddin, 2002) and some of them are endemic (around 381 spesies). The increasing habitat degradation has led to the fact that nearly 400 species of birds are now threatened with extinction (Thinh, 2006).

One of bird groups that are interesting to study is migratory birds. This group is a bird group that move from one region to another, either inter-island or intercontinent, and will return to their origin (Shackelford et al., 2005). This migration occurs because of seasonal change or the birds feeding habits in a relatively far distance. Small islands in Indonesia provide habitats for a variety of migratory bird species to stopover. Habitat characteristic of various ecosystems in each island possesses its own specific and unique characteristics. Often, these migratory birds can attract tourists visiting the islands (Aeny, 2004).

One of small islands (Lombok: small island = gili) that exist around Lombok Island is Gili Meno. This small island is one of three islands included in Gili Matra village. Gili Meno is well-known for its specific and unique salt water lake (Rachman, 2004) and has a pleasing panorama. Moreover, its ecosystem also saves a great potential of various exotic animal species. Research conducted by Setiawan (2008) explained that no less than
11 species of migratory birds use the habitat to stopover in migration season. Some of them are Phalacocorax melanoleucos, Actitis hypoleuco, Ardea purpurea and Charadrius dubius.

To date, several researches have been carried out to identify many migratory bird spesies in the ecosystem of salt water lake of Gili Meno, one of them is by Setiawan (2008). However, in the research, field observation was only performed once and the researcher has not done a study of microhabitat and factors that make the salt water lake as one of preference habitat for migratory birds. Therefore, this research was conducted to identify the diversity of migratory bird species in the ecosystem of salt water lake of Gili Meno and recognize the habitat characteristics that could support the wild birds' lives in the ecosystem.

\section{Materials and Methods}

The objects of this research were migratory birds utilizing the lake as their activity place. This research was undertaken in September and October 2013. The first data collection was performed on the $24^{\text {th }}-26^{\text {th }}$ of September and the second data collection was completed on the $18^{\text {th }}$ $20^{\text {th }}$ of October 2013. Data collected were bird species, mangrove vegetation and fish species.

Data collection of bird species was conducted on field in the morning from 07.00-10.00 and in the afternoon from 15.00-17.00. The observation was performed in 4 
spots which were determined purposively on field. Bird species were observed and identified by directly observing morphological features and characteristics of the birds based on a guide to the birds of Wallacea (Coates and Bishop, 2000). Morphological features observed included: (i) shape and size of body, beak and feet, (ii) the colours of feather on body, beak, and feet, (iii) visible specific features, as well as (iv) sounds produced.

Analysis of mangrove vegetation was performed on sampling spots that have been directly marked by a GPS device. The vegetation analysis was undertaken by making $10 \times 10 \mathrm{~m}$ quadrants. Obtained vegetation data included vegetation species, trunk diameter, and the individual number of each species. Furthermore, fish were caught utilizing a fish net in cooperation with local community. The vegetation data were then analysed by calculating density, Frequency, Dominance, IVI, and Shannon-Wiener Diversity Index (H').

\section{Results and Discussions}

A total of 17 species belonging to 5 families have been identified in this research. The five bird families are Scolopacidae, Charadriidae, Ardeidae, Meropidae dan Alcedinidae. Of the 17 identified species, 16 species are migrants (Table 1). The non-migrant bird and inhabitants of Gili Meno is the species of Halcyon sancta.

Black-crowned Nirgt-heron (N. Nycticorax) is a species with the highest population identified. As stated by Coates and Bishop (2000), this species is a migratory species that reproduce in their migration sites. On several observation spots in the vicinity of mangrove forest, their active and already inactive nests were discovered. In addition to that, it was observed that Striated Heron $(B$, striatus) was also on fairly high population number. Both bird species are known to prefer similar habitat which is mangrove area, muddy sites and shallow puddle (Zulfan, 2009; Setiawan 2008; Mustari, 1992). These species difference is in their feeding activity. Nycticorax nycticorax was more often spotted perched on tree branches and once in a while went down to catch small fish. Meanwhile, B. striatus was more active and often walked around the lake to find preys.

This research discovery is supported by previous research conducted by Setiawan (2008) who also discovered both bird species in high individual number. It was further stated that mangrove ecosystem in salt water lake of Gili Meno could highly sustain the existence of the two species population. Additionally, food availability in the vicinity of lake and the lake's proximity to adjacent beach also provided more varied habitat choices for these birds.

Other fairly numerous migratory bird species discovered during this research were those belong to Trinil category i.e: Common Sandpiper (Actitis hypoleucos), Wood Sandpiper (Tringa glareola), Marsh Sandpiper (Tringa stagnatilis) and Common Redshank (Tringa tonatus). Detailed observation has successfully identified the four species clearly. Detailed observation was necessary because occasionally, these four species were in large group $(>10)$. The observation of these bird species was basically simple to perform due to significant differences in size and features of each species. Nevertheless, A. hypoleucos and T. glareola were often found feeding in pairs or individual on the lake shore.

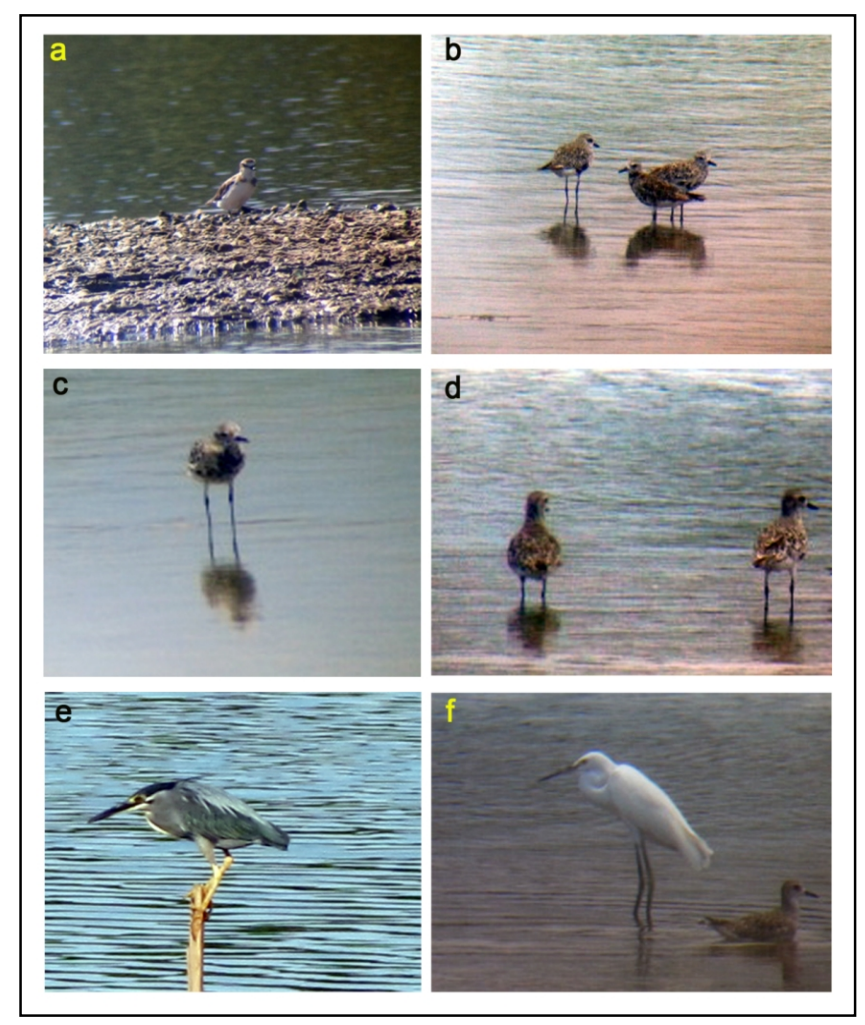

Figure 1. Documented bird species. a. Cerek Jawa (Charadrius javanicus Chasen, 1938); b \& c. Cerek Besar (Pluvialis squatrola); d. Trinil Semak (Tringa glareola Linnaeus, 1758); e. Kokokan Laut (Butoroides striatus); f. Kuntul Kecil (white) (Egretta garzetta), Trinil Pantai/small brown (Actitis hypoleucos).

Another migratory bird category is Cerek including Little Ringed Plover (Charadrius dubius), Javan Plover (C. javanicus) and Grey Plover (Pluvialis squatarola). Two of the three species (C. Javanicus and Pluvialis squatarola) have not been reported in the study conducted by Setiawan (2008), this might be because of different observation time. According to Coates and Bishop (2000), both species are migratory birds and do not reproduce so that sometimes they are not observed in certain time. It was further explained that the three species prefer shallow and calm mangrove habitat, natural habitat and far from human activity. This result demonstrate that the thre migratory species presence can be utilized as habitat indicator that salt water lake of Gili Meno can support the lives of wild animals. Mulyawati (2007) also reported that this bird group likes muddy mangrove area and shallow water.

The next bird category observed was Kuntul comprising 3 species: Little Egret (Egretta garzetta), Reef Egret (E. sacra) and Intermediate Egret $(E$. intermedia). The population of E. Garzetta was the 
highest of the three species with the highest individual number observed on field was 16 individuals. This species occupied almost half of the lake's shore around 08.00-09.00 and 15.00-17.00 when they are actively feeding. On the other hand, E. intermedia was only found 4 individuals at the most during the research. Posture, larger body size and typical beak colors (bright yellow) appears to distinguish the two species. Unlike $E$. garzetta and E. scara, E. intermedia often becoming active between 09.00-10.00 and sometimes it was not observed in the afternoon. Meanwhile, E. sacra was rarely seen lingering around the lake. This may be due to food competition on the lake shore. The species was mostly spotted on the beach shore at low tide in the afternoon then returned to the mangrove ecosystem afterward.

Table 1. Birds species discovered in salt water Lake Ecosystem of Gili Meno.

\begin{tabular}{llll}
\hline Family & Indonesia & English & Latin \\
\hline Scolopacidae & Trinil Pantai & Common Sandpiper & Actitis hypoleucos \\
& Trinil Semak & Wood Sandpiper & Tringa glareola \\
& Trinil Kaki Merah & Common Redshank & Tringa tonatus \\
& Trinil Rawa & Marsh Sandpiper & Tringa stagnatilis \\
Gajahan Erasia & Eurasian Curlew & Numenius arquata \\
Charadriidae & Cerek Kalung Kecil & Little Ringed Plover & Charadrius dubius \\
& Cerek Jawa & Javan Plover & Charadrius javanicus \\
Ardeidae & Cerek Besar & Grey Plover & Pluvialis squatarola \\
& Cangak Merah & Purple Heron & Ardea purpurea \\
& Kuntul Perak & Intermediate Egret & Egretta intermedia \\
& Kuntul Kecil & Little Egret & Egretta garzetta \\
& Kuntul Karang & Reef Egret & Egretta sacra \\
Kowak Malam Abu & Black-crowned Nirgt-heron & Nycticorax nycticorax \\
Alcedinidae & Kowak Malam Merah & Rufous Nigtt-heron & Nyicticorax caledonicus \\
\hline
\end{tabular}

Other bird species that were observed around the lake were Sacred Kingfisher (Halcyon sancta) and BlueTailed Bee-eater (Merops philippinus). Sacred Kingfisher often noticed on several spots on the lake shore to catch small fish. Decreasing lake water has led to higher salinity causing small fish to surface, so that it was easier for the birds to catch their prey. Occasionally, Sacred Kingfisher produced strong sounds when they flew or met the same species. In contrast, M. philippinus was more aereal. This species make use of mangrove habitat as feeding site which provide abundant insects.

Mangrove ecosystem is an integral part of the ecosystem of salt water lake of Gili Meno. This mangrove ecosystem provide excellent microhabitat for many wild animals, especially migratory birds. As stated by Elfidasari and Junardi (2006), one of many functions of mangrove is as nesting and stopover sites for various bird species. Healthy mangrove ecosystem is more preferred and visited by many bird species as it provide huge potential as food sources.

Mangrove ecosystem in Gili Meno consist of three mangrove species: Avicennia lanata, Avicennia marina dan Exoecaria agallocha. The calculation of species relative dominance showed that $A$. marina dominate the habitat in the ecosystem of the salt water lake $(69.45 \%)$, followed by A. lanata (23.81\%) and E. agallocha (6. $74 \%$ ). Moreover, relative species density index also illustrated a fairly dense coverage of $A$. marina. In contrast, species diversity index $(0.565)$ demonstrated the low species diversity in the mangrove ecosystem because of $A$. marina dominance.

In addition to plant resources, the habitat of salt water lake of Gili meno also offer animal resource for migratory bird feeding. The mangrove ecosystem ability to maintain the stability and fluctuation of salinity and temperature causes fresh water species capable to adapt in the saltwater habitats. From the results of fishing using fishing nets and rods it was found that only one species of fish inhabit the whole habitat of the salt water lake. The identified species is Mujair fish (Oreochromis mossambicus). As indicated by Kosztowny et al (2008), this fish species can adapt well in salt water from juvenile. This is becaue of its ability to activate ATPase anzyme to maintain cell membrane activity, especially on the gill rackers to keep active despite the high salinity. Further research to identify other animal species which is potential as feeding resource for migratory birds is of high importance. Moreover, research on the histological and anatomic differences of Mujair fish from salt water and fresh water is required. 

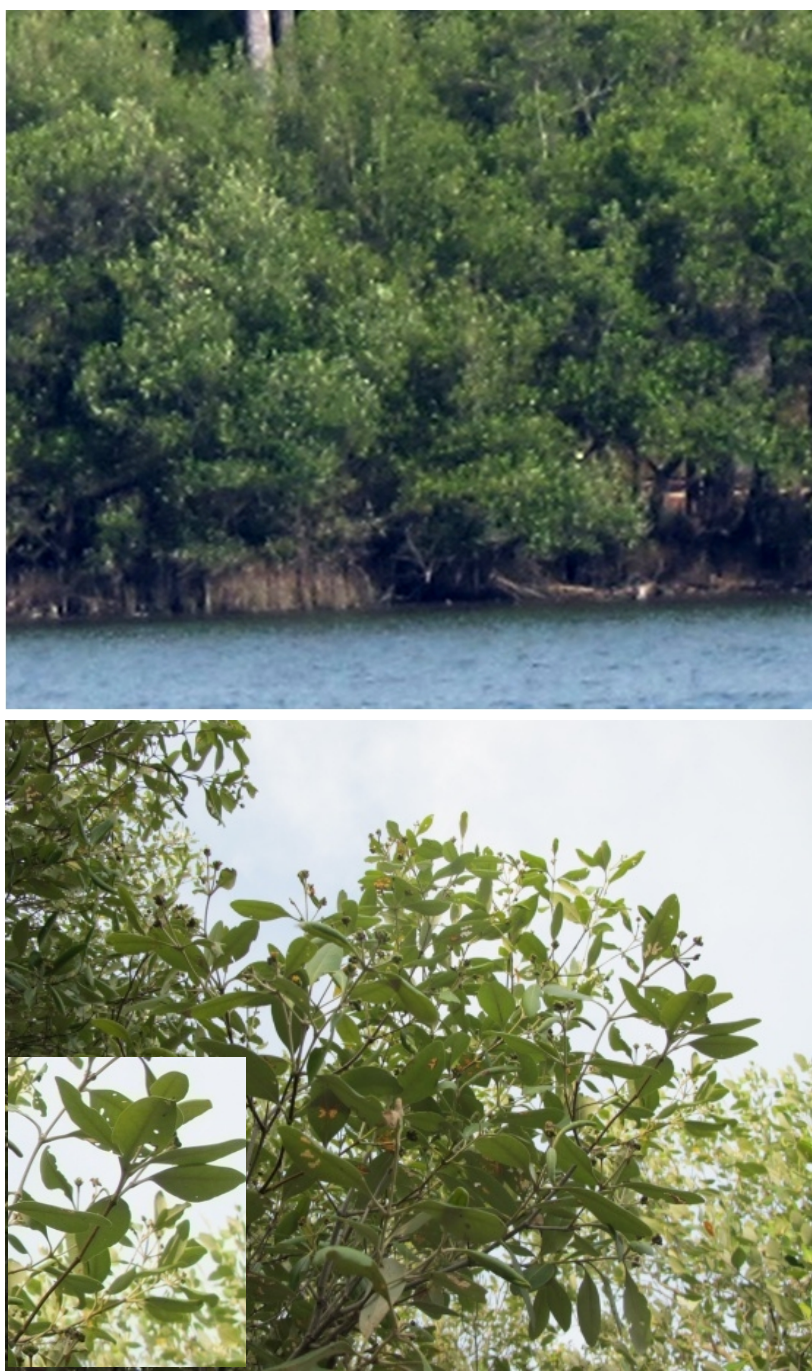

Figure 2. Coverage shape and characteristics of mangrove a. Avicennia marina with close coverage along the lake shore b. Oval leaf tip shape with white lower leaf surface is the diagnostic character of A. marina.

The calculation of Importance value Index (IVI) showed that the most important species was A. marina. This species was discovered almost in all ecosystem area around the salt water lake. This was supported by the calculated diversity index of Shannon-Wiener which showed the low diversity of mangrove vegetation in the ecosystem. In other words, the ecosystem is dominated by A. marina.

The existence of mangrove vegetation in a habitat will form a spesific ecosystem and provide abundant resources. Davies et al., (1996) stated that mangrove ecosystems have important roles in sustaining the lives of animals on coastal line and terestrial. Mangrove vegetation in the ecosystem of salt water lake of Gili Meno also provide abundant feeding resource for migratory birds like small insects and fish. This is also supported by Abdurakhman (2002) research who discovered that food availability in a habitat will be more frequently visited by animals (burung). Yamin and Jamaludin (2002) also explained that excellent vegetation will provide diverse resources to sustain bird lives in a habitat.

Dominant bird species observed in this study is Blackcrowned Nirgt-heron (N. nycticorax) and Striated Heron (B. striatus) which are migratory birds that reproduce in their migration sites (Coates and Bishop, 2000). Both species made many nests on dense mangrove tree canopy. These species have successfully dominated the ecosystem of salt water lake of Gili Meno may because both species can obtain their suitable life requirements such as food, nesting place and shelter from predators.

Other migratory birds which belong to Trinil category (A. hypoleucos and $T$. glareola) often spotted fly actively and walked along the shallow lake shore to find food. Both species are different from other two species from the same group (T. stagnatilis and T. totanus). T. stagnatilis and $T$. totanus are relatively not very active and often observed in groups. The high availability of small fish and water insects on the surface of the lake make the lake habitat is mostly preferred by many migratory bird species. The lake ecosystem which almost $90 \%$ covered by mangrove vegetation contribute to the ideal condition of the habitat for migratory birds to stopover.

The fairly dense mangrove vegetation which surround the salt water lake ecosystem has formed a characteristic and sustainable habitat for many wildlife including migratory birds. Habitat with dense canopy and which tend to be wet is more favored by birds (Mulyawati, 2007; Anonim $^{\mathrm{a}}, 2000$ ). Additionally, a relatively shallow, sandy and muddy area is a preferred area for migratory bird species. This research discovered that the migratory birds were more concentrated on the southern area of the lake. This area is relatively shallow, muddy to sandy, has denser mangrove coverage and more importantly, is far from road access (human activity). Birds distribution map that has been prepared cleary shows that the main characteristic of preferred habitat of migratory birds is habitat with wet, shallow, sandy to muddy land, as well as dense vegetation canopy and which is far from human activity.

Table 2. Data analyses of mangrove vegetation biodiversity.

\begin{tabular}{|c|c|c|c|c|c|c|c|}
\hline \multicolumn{2}{|c|}{ Name } & \multirow{2}{*}{ Sum } & \multicolumn{5}{|c|}{ Value } \\
\hline Indonesia & Latin & & RDen & $\mathbf{R F}$ & RD & IVI & $\mathbf{H}^{\prime}$ \\
\hline Api-api putih & Avicennia marina & 23 & 22,55 & 42,11 & 23,81 & 88,46 & \\
\hline Api-api & Avicennia lanata & 79 & 77,45 & 42,11 & 69,45 & 189,01 & 0,565 \\
\hline Buta-buta & Exoecaria agalocha & 8 & 7,84 & 15,79 & 6,74 & 30,37 & \\
\hline
\end{tabular}

Explanation:

RDen : Relative Density $\quad$ RF $\quad$ Relative Frequency

IVI : Importance Value Index

H' : Shannon-Wiener Diversity Index 


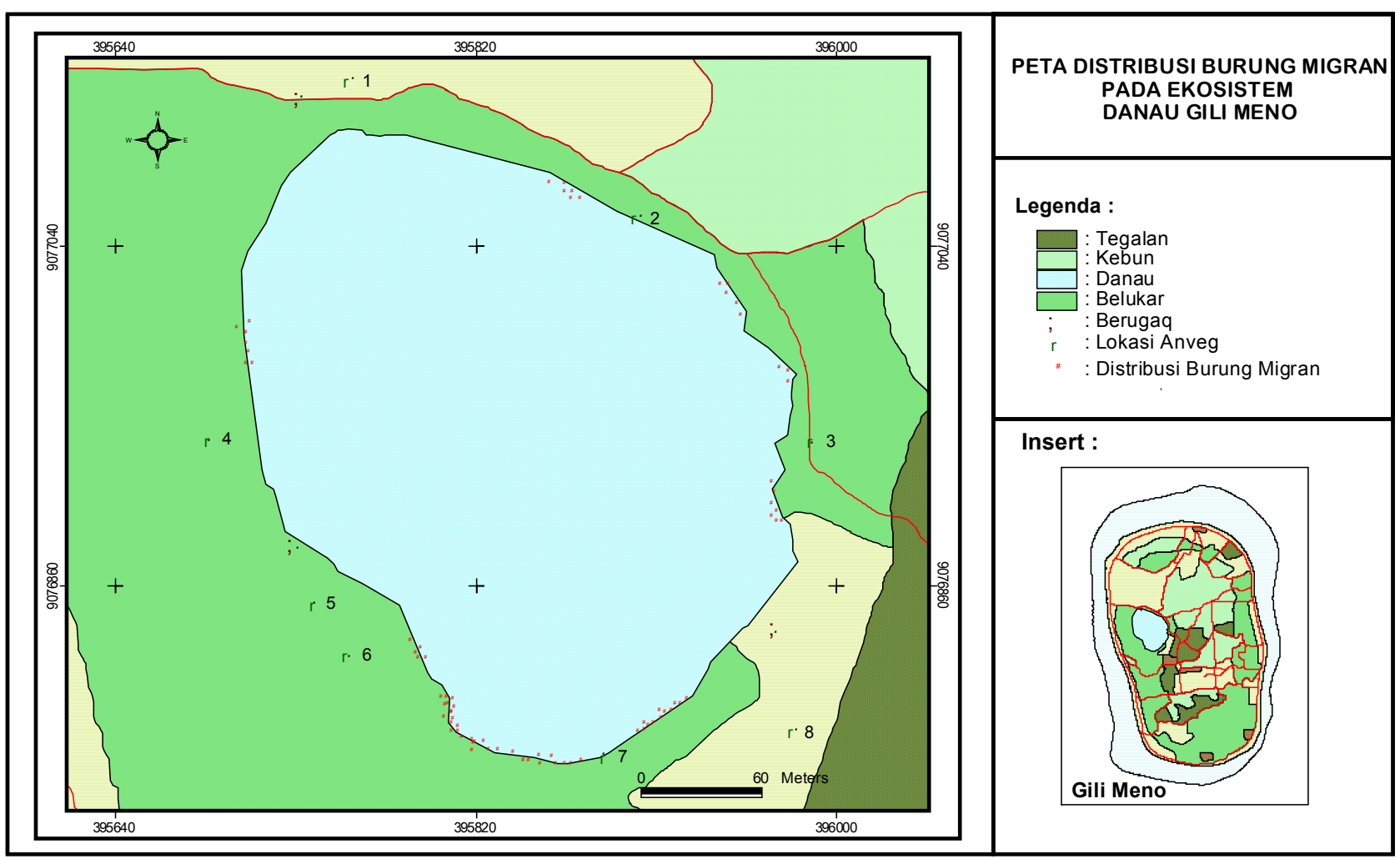

Figure 3. Distribution map of migrant birds in a salt water lake of Gili Meno. From this map, it is clear that migratory birds (red spots) are more active in the south of the lake. This is supported by the shallow banks of the, dense mangrove coverage and the far location from human activity.

Natural and undisturbed habitat is more favored by migratory birds. Habitats with high canopy and dense mangrove coverage provide nesting places, protection, nursing site and suitable feeding resources. Shallow and sandy to muddy areas can facilitate birds to find food especially small fish. In addition, areas that are far from road access and human activity, are safer and unstressful. These characteristic factors are specific for the habitat of salt water lake of Gili Meno which in turn make it a favored place to stopover during migratory season. New species observed in this habitat which was undiscovered in previous research was Javan Plover (Charadrius javanicus). This species has been reported to migrate along the shoreline of Sumatera, Kalimantan, Java as well as Bali and just reported in 2011 to stopover in several habitats in West Nusa Tenggara (Anonim c, 2013; McKinnon, 1991). This may because of decreasing quality of habitats in western part of Lombok Island so that the species chose healthier habitat to migrate to. The presence of this migratory bird also indicates that the ecosystem of salt water lake of Gili Meno is still in a good condition and therefore should be protected.

Overall, bird species discovered during this research were higher in number than those observed by Setiawan (2008) in August 2008. It is assumed that different observation time take part in the different result from this research. However, this research did not discovered Pecuk Padi Belang (Phalacocorax melanoleucos) which were present in Setiawan's research. These data should be updated to identify whether habitat change (habitat degradation) or migration season and observation time is the determining factor which affect the absence of several bird species.

\section{Conclusion}

There are 17 bird species identified in this research belonging to 5 families i.e. Scolopacidae, Charadriidae, Ardeidae, Meropidae and Alcedinidae. Of the 17 species discovered, 16 species were migratory birds. In addition, this research also uncovered the especially high population of $N$. nycticorax followed by B. striatus. This study also identified 3 species of mangrove: Avicennia marina, A. lanata and Exoecaria agallocha as well as one species of fish (Mujair fish/Oreochromis niloticus). The existence of the fairly good mangrove vegetation and sufficient food availability contributed to the ideal condition of the habitat of saltwater lake of Gili Meno as migration site for birds during migration seasons.

\section{Acknowledgment}

We express our gratitude to the Birdwatching group in Gili Meno who supported us in fieldwork and provided us more information about several mangrove species. We also thank Mr. Andy Setiawan who has provided his assistance in the indentification of birds' population and fieldwork documentation. All parties who cannot be all mentioned in this article is also acknowledged for their support during field study and data analyses. 


\section{References}

Abdurakhman. 2002. Stratifikasi Penggunaan Habitat Berbagai Jenis Burung Di Sekitar Danau Gili Meno-Lombok Barat. SKRIPSI FKIP Jurusan Biologi Universitas Mataram. Mataram.

Aeny, W. 2004. Keanekaragaman Jenis dan Pemanfaatan Jenis Tumbuhan Oleh Burung Liar Di Kota Mataram. SKRIPSI FKIP Jurusan Biologi Universitas Mataram. Mataram.

Anonima . 1992. Ensiklopedia Indonesia Seri Fauna Burung. PT. Intermasa. Jakarta.

Anonim ${ }^{\mathrm{b}}$. 2006. Jenis-Jenis Burung Dilindungi yang Sering Diperdagangkan.

http://www.kehati.or.id/news/data/8,\%20)kt2000\%20info \%20kehati.pdf. Downloaded on 19/11/2012. 10.30 WITA.

Anonim $^{\mathrm{c}}$, 2013. Burung-Burung di Kawasan Indonesia. www.kutilang.or.id

Coates, B. J., dan Bishop, K. D. 2000. Panduan Lapangan BurungBurung di Kawasan Wallacea. Bird Life InternationalIndonesia Programme \& Dove Publications Pty. Ltd.

Davies, J., G. Claridge, dan C.H.E. Niranita. 1996. Manfaat Lahan Basah Dalam Mendukung dan Memelihara Pembangunan. Bogor: Direktorat Jendral PHPA \& Asian Wetland Bureau.

Elfidasari, D dan Junardi. 2006. Keanekaragaman Burung Air di Kawasan Hutan Mangrove Peniti Kabupaten Pontianak. Biodoversitas. Vol.7 No.1, pp: 63-66.

Kusmana, C. 1997. Metode Survei Vegetasi. PT. Institut Pertanian Bogor. Bogor.

Kosztowny, A.L., T. Hirano and E. G. Grau. 2008. Developmental Changes in $\mathrm{NA}^{+}, \mathrm{K}^{+}$-ATPASE Activity in Mozambique Tilapia (Oreochromis mossambicus) Embryos and Larvae in Various Salinities. International Symposium on Tilapia in Aquaculture.
MacKinnon, J. 1991. Panduan Lapangan Pengenalan BurungBurung di Jawa dan Bali. Gadjah Mada University Press. Yogyakarta.

Mulyawati, D. 2007. Migrasi Burung. Buletin Burung III/edisi Januari 2007. Bogor.

Mustari, A.H., 1992. Jenis-Jenis Burung Air Di Hutan Mangrove Delta Sungai Cimanuk Indramayu-Jawa Barat. Media Konservasi. Vol. IV; pp: 39-46.

Noor, Y. R., M. Khazali dan I. N. N. Suryadiputra. 2006. Panduan Pengenalan Mangrove di Indonesia. PHKA/WI-IP. Bogor.

Rachman, R. 2004. Identifikasi Potensi Wilayah Nusa Tenggara Barat. Percetakan Sahabat. Mataram.

Setiawan, A. 2008. Karakteristik Habitat Burung Di Gili Meno Desa Gili Indah Kecamatan Pemanang Kabupaten Lombok Barat. SKRIPSI MIPA Jurusan Biologi Universitas Mataram. Mataram.

Shackelford, C. E., E. R. Rozenburg, W.C. Hunter and M.W. Lockwood. Migration and Migratory Birds of Texas $4^{\text {th }}$ edt. Texas Parks and Wildlife PWD, USA.

Sudaryanto. 2006. Birdwatching. Accessed from http://sudaryantoornito/blog.com/. 21/11/2012.11.23 WITA

Thinh , V., T. 2006. Bird Species Richness and Diversity In Relation Vegetation In Bavi National Park, Vietnam. Ornitology Science, 5: 121-125.

Yamin, M. dan Jamaluddin. Populasi Dan Asosiasi Koak-Kao (Philemon buceroide) dengan Beberapa Jenis Tumbuhan Pada Habitatnya Di Taman Buru Pulau Moyo. Laporan Penelitian Dosen Universitas Mataram. Mataram.

Zulfan, 2009. Keanekaragaman Jenis Burung Di Hutan Mangrove Krueng Bayeun, Kabupaten Aceh Timur Provinsi Nanggroe Aceh Darussalam. [Skripsi]. Institut Pertanian Bogor, Bogor. [Indonesia]. 